\section{An English Magus Comes at Last to Hungary}

Szönyi György Endre: "Exaltatio és hatalom." Keresztény mágia és okkult szimbolizmus egy angol mágus müveiben ["Exaltation and power" Christian

Magic and Occult Symbolism in the Works of an English Magus] (Szeged: JATEPress, 1998)

In Hungary it is not easy to find a scholarly book on either Hermeticism or Christian magic, let alone on the English magus John Dee. Though interest has increased considerably in recent years and the number of books on related topics has mushroomed, academic interest has been very scant until very recently.

Most works concerned in this controversial area appear to be markedly for or against, either eulogising more commendable and alternative Vorstellungsarten, accepting the Hermetic teachings and the New-Age ideology at face value, or condemning the magical world-view as a stubborn weed, a prescientific surrogate for rational thinking still poisoning our culture.

As key texts have not been translated for centuries, and most of the translations are not from the original languages, ${ }^{6}$ it is very good news that György Endre Szőnyi's book on John Dee's life, work, and main influences appeared in 1998.

\section{I.}

The chapters of the book are somewhat diverging, but they are all centred around John Dee (1527-1608), "one of the ornaments of his Age" a most colourful figure of the otherwise not-sodull Elizabethan England. For some primarily a philosopher, for others a mathematician, a great librarian, an influential court astrologer, or simply a conjurer and magician, ${ }^{8}$ Dee influenced

${ }^{6}$ Just one example: the Hungarian translation of the Corpus Hermeticum is based on the pioneering but dated four-volume translation of W. Scott though it has been retranslated many times before Copenhaver's new translation in 1992.

${ }^{7}$ As John Aubrey described him in 1718. in Peter J. French, John Dee: The World of an Elizabethan Magus (London: RKP Ark Paperbacks, 1972) p. 4.

8 Much has changed when in 1659 Meric Casaubon (the son of Isaac Casubon, who eventually proved that the Hermetic writings, so influential in the Renaissance, were postChristian) published excerpts form Dee's diaries about 'what passed for many Years Between Dr: John Dee... and Some Spirits'. The book known 
many and was one of the most learned men of his time. He selected the most propitious day for Elizabeth's coronation; improved the Julian calendar (but his much admired improvements were rejected by the bishops); and had visitors such as Sir Philip Sidney, the Secretary Sir Francis Walsingham, and Queen Elizabeth, to his home in Mortlake. His life was not without difficulties; he was imprisoned in 1555 on the charge of having enchanted the Queen, and was subsequently tried on ecclesiastical charges, but released; his life-long quest for patronage was never fully successful, and after a life of much admiration and scorn he died poor and neglected.

Many interesting anecdotes have survived from this exceptionally welldocumented life, ${ }^{9}$ and, as Dee recorded

as "A True \& Faithful Relation", established Dee as a fanatic deluded by devils.

9 For his private life see: "Deborah E. Harkness, "Managing an Experimental Household - the Dees of Mortlake and the Practice of Natural Philosophy" ISIS 88 (1997) pp. 247-263. Apart from some harsh words such as "today psychologists would be tempted to label John Dee a clinical narcissist or an anal retentive for his exhaustive documentation of everything from his astrological consultations to his wife's menstrual cycles...", Harkness describes a strange agreement in April, 1587 between Dee and his his book purchases meticulously, his intellectual development can be studied with relative ease.

II.

After outlining the task of the book and providing an overview of the chapters, Szönyi describes in detail how he intends to tackle the occult and magic tradition and world-view in the first part. The book's organising principle, the Latin term exaltatio is also introduced.

The second part offers a biography of John Dee, with special emphasis on the years 1583-89, which Dee spent in Central Europe. It describes in detail Dee's journey to Pozsony [present day Bratislava] in 1563, where he took part in the coronation-ceremony of Maximilian of Habsburg (to whom he later dedicated the famous Monas bieroglyphica) The biography contains many amusing details, and gives a largescale overview of Dee's life from his

medium, Kelly on the "common and indifferent using of Matrimonial Acts amongst any couple of us fourn, to which the wives agreed after "weeping and trembling for a quarter of an hour". After consummation of the 'pactum factum' the angelic revelations increased, and new information was available for Dee on the Apocalypse. 
early days and arduous University years at St John's College, Cambridge through his peregrinations in Europe, to his mature years in Mortlake. It sketches the continuously changing focus of his interests: "first excellency in mathematics and enthusiasm for natural scientific questions, followed by an increasingly historical - ideological interest, and ending in the most esoteric occult philosophy, which meant a gradual turning away from the empirical sciences." 10 Szönyi believes that in Dee's life "the esoteric tradition of European humanism was undoubtedly united with the subconscious processes of a psychologically hypersensitive person." ${ }^{11}$

The third part of the book is a historical Rückblick which gives an overview of twentieth century developments in research into hermeticism, with special emphasis on the work of Frances Yates. It also introduces and discusses some of the Renaissance writers that influenced Dee. A substantial part of the chapter is devoted to the rediscovery, translation, and early interpretations of the Hermetic writings, focusing on the Pimander

${ }^{10}$ Szönyi p. 42 . The translations are mine. G.Z.

${ }^{11}$ Szönyi p. 46. and the Asclepius of the Corpus hermeticum, and also to the analysis of two influential medieval works on magic: the Picatrix (first translated from the original Arabic to Spanish in 1256, and later to Latin), a short book on talisman-magic, and the Liber secretorum (which was for a long time mistakenly attributed to Albertus Magnus).

Throughout the whole book Szönyi's method is to characterise an age through analyses of selected works from carefully chosen authors; as an example he describes the christianization of magic through the writings of Marsilio Ficino (1433-1499) and Pico della Mirandola (1463-1494) ${ }^{12}$.

In the next epoch the works of Henry Cornelius Agrippa (1486-1535) and Paracelsus (app. 1493-1541) illustrate the emergence and aims of 'naturall magick,' which evolved mainly from theoretical speculations by the sixteenth century, when it encountered a crisis. Both writers influenced Dee profoundly, in fact, he pioneered the study the Paracelsian writings in

\footnotetext{
${ }^{12}$ Surprisingly little of Ficino and Pico has been translated into Hungarian, and even these are smaller essays like Marsilio Ficino, "Kratülosz, vagy $A$ nevek valódi értelme - A Platón dialógus argumentuma" transl. Klára Pajorin Helikon 3-4 (1992) pp. 338-347.
} 
England. Agrippa von Nettesheim was the most eminent pupil of Johannes Trithemius (1462-1516, engaged mostly in applied magic), and became known all over Europe with his De occulta philosophia, uniting medieval magia naturalis concepts with Neoplatonic ones. Szőnyi, however, investigates not only this work, but also Agrippa's much more sceptical De incertitudine, a work that rejects the possibility of certain knowledge and questions the usefulness of [empirical] science. A single, unified world-view can be postulated behind the two, however, even if the two works appear to contradict each other, since in the 1533 edition of De occulta philosophia Agrippa incorporated those chapters of De incertitudine that reject magic and Hermeticism most openly. Thus, Szőnyi claims, with Agrippa we find for the first time the recognition of a paradox inherently present in the magic world-view.

The chapter ends with a close reading of the scientist-magician Paracelsus' two books, to show how 'magic was scientized' in his Paragranum, and of his Astronomia magna, to illustrate an example of hermetic natural philosophy.
The fourth and last part of the book returns to Dee, closely investigating his natural philosophy and occult symbolism $^{13}$. After an historiographical introduction Szönyi traces how Dee's occult philosophy develops in his three major works

In the Propedeumata aphoristica (1557) Dee develops a method for measuring the distances of heavenly bodies, so that the astrological constellations can be computed with more precision. The improved method, however, required the calculation of 25 341 constellations instead of the usual 120 , which was practically impossible in Dee's time. This obstacle diverted Dee's attention to other areas.

After portraying the main theses of Dee's Monas hieroglyphica (1564) and the Mathematicall Preface (1570), probably the most famous of Dee's works, Szönyi investigates the most curious area of Dee's life: his long preoccupation with cabalist angel-magic which he follows with short summaries of the magic tradition, Renaissance symbolism, the

\footnotetext{
${ }^{13}$ For a short study on the importance and interpretation of visual symbols see for example "Urszula Szulakowska, "Geometry and Optics in Renaissance Alchemical Illustrations: John Dee, Robert Fludd and Michael Maier" in Cauda Pavonis Studies in Hermeticism, 14 No.1 (1995).
} 
development of the Faust motive, and the change in attitude toward magic. The book ends with a general evaluation of Dee's life and work.

\section{III.}

Although two chapters from the four are not concerned with Dee directly, this is to be applauded not scorned, knowing the scarcity of valuable scholarly studies on this topic in Hungarian.

If we look for an organising principle in this multi-faceted tableau, we might say that it attempts to highlight the elements which flowed from Judeo-Christian culture into high European culture, that influenced Dee.

In treating the analysed texts as works containing some kind of culturalhistorical truths, he aims to give a creditable, but not necessarily objective analysis that takes into account and incorporates the peculiar paradoxes inherent in magic. He rightly does not propose to judge or decide whether Dee's last years were those of enlightenment or madness.

Magic is treated as an independent discipline, not as a primitive phase ${ }^{14}$ in

\footnotetext{
${ }^{14}$ See for example works of Walter Pagel like Vindication of Rubbish (1945), Paracelsus (1958), etc.
}

mankind's cultural history. Magic is a kind of act, which, with the help of occult knowledge unites the human spirit with the supernatural, enabling him to exercise his power in the spiritual world, and finally raises him to a level of divinity, so that he enters the world of ideas in earthly life. This concept, which reappears throughout the book is called exaltatio by Szonnyi. For him this higher organising principle is present in all the Renaissance works analysed.

\section{IV.}

It is impossible today to write about the Renaissance hermetic tradition without mentioning Frances Yates, and without a critique of the Yates-thesis, and Szönyi devotes a whole chapter to this topic. In several places he criticises the Yates thesis, which states that the Renaissance magus is the immediate predecessor of the seventeenth century scientist. The structure of the whole book and the works he chooses to investigate, however, show that he is much indebted to Dame Frances.

Much of his criticism is directed against the too strong claims of Yates, and the coarseness of the picture she depicts. To give just one example, when discussing the origins of Ficino's magic, 
Szőnyi gives a more detailed and subtle interpretation than Yates. Though she described medieval magic extensively in her books, Yates claims that Ficino turned away from this crude and primitive tradition. She believes that neo-platonism in Florence originates almost exclusively from the Hermetic tradition. Szönyi, on the other hand, holds that the medieval roots were important to understand Ficino's magic, and as, for example, the Picatrix is an Arabic treatise based on the classical tradition, there is little reason to call it 'primitive.' He claims that it is very important and pointing forward that there was a need to unveil the hidden truths, stress the central importance of man and of the scientific understanding. The magic preserved by the Arabic culture thus is a connecting link not only with the philosophical theology of the Florentine Neoplatonists, but also with the late renaissance acceptance of the experimental natural sciences.

Whether true or not, this opinion shows no major revision of the original Yates-thesis, seeing a direct link between the Hermetist and the seventeenth century scientist.

\begin{abstract}
V.
While traditions of magic usually influenced and accompanied artistic work in the fifteenth century, the magus was increasingly seen as a scientific figure in the sixteenth. One of the most memorable scientist-magicians is the not-always-polite Paracelsus ${ }^{15}$. Szönyi concentrates on his philosophical views, drawing his citations from the Paragranum and the Astrologia magna. Unfortunately, he devotes scant attention to Paracelsus the 'scientist,' and does not attempt to show the connections between his scientific writings and magical world-view.

What makes this even more regrettable is that the only comprehensive book available for the Hungarian reader on the History of Chemistry ${ }^{16}$, only treats Paracelsus as a 'protochemist,' giving a painfully one-sided picture about him, and neglecting all other aspects relevant to our

\footnotetext{
${ }^{15}$ See, in Hungarian, for example: Paracelsus, Credo in József Pál, ed., Hermetika, mágia ezoterikus látásmód és mûvészi megismerés. Szöveggyûjtemény; Ikonológia és mûértelmezés 5. monographs on Paracelus.

${ }^{16}$ Balázs Lóránt, $A$ kémia története I-II. [The History of Chemistry] (Nemzeti Tankönyvkiadó, 1996).
} (Szeged: JATEPress, 1995), or any of the detailed
\end{abstract}


understanding of "Thephrastus Bombastus."

This 'presentist bias' is still very common in Hungarian works on the history of science. There are exceptions, but as most writers are scientists rather than historians, they prefer internalist and 'modern-minded' accounts.

On the other hand, although Szönyi consciously attempts to evade the usual mistakes of writing history, he is reflexive towards both his source and his own story, the reader is left unsatisfied, as the chapter entitled 'Occult history and natural science,' apart from some very general remarks, has very little to say about natural science, and thus evades the important issue. This means that though both works mentioned deal with the complex figure of Paracelsus, they both fail to provide a balanced picture. Instead of offering an outline of Paracelsus' work in the natural sciences (which the title of the chapter suggests ${ }^{11}$ ), Szönyi only

${ }^{17}$ The chapter title "Occult philosophy and natural science" is thus somewhat misleading. From the eighties onward, some excellent commentaries have appeared, like "Keith Hutchison, "What happened to the Occult Qualities in the Scientific Revolution?" ISIS 73 (1982) p. 267; or Brian Vickers, ed., Occult and Scientific Mentalities in the Renaissance. gives a - surprisingly - detailed account of Jung's reading of Paracelsus.

We can only agree with Szönyi that it is very difficult to employ the language of rationalistic, positivist science when the topic under discussion is a view of the world that is antagonistic to any form of discursive thinking, and aims at providing an alternative to it.

Szönyi painstakingly shows how large-scale histories and master narratives aimed at giving an overview from a scientific or religious viewpoint deform Dee's figure by stressing only one side of his endeavours. Of course all history-writing necessarily implies the acceptance of some kind of master narrative. It is impossible, however one may try, to escape this trap, as already picking the topic and the relevant connections worthy of discussion presupposes a large-scale narrative: "the

(Cambridge Uni. Press, 1984), this has a good introduction by Vickers and an article on Dee by N. H. Clulee. Also of interest is the article: Fehér Márta, "The 17th century crossroads of the mathematizaton of nature" in Changing Tools Case Studies in the History of Scientific Methodology (Budapest: Akadémiai Kiadó, 1995) pp. 1-26, which outlines an alternative to the Yates-thesis that follows in the footsteps of Mary Hesse. 
historian's choice of subject matter and way of framing the questions to be asked of it are themselves always determined by reference to an existing historiographical picture." ${ }^{18} \mathrm{He}$ introduces his own organising principle, however: the framework of exaltatio. This serves well as an approximate organising principle, but, to my belief, is not able to replace the (rightly criticised) master-narratives of the histor of science.

The book is demythologising, as the reader has to relinquish many fancy conceptions about Dee: he had no major impact on either the development of European science, or the cultural heritage of Central Europe and Hungary. These misconceptions result from distorting, one-sided masternarratives which inevitably lead to the homogenising of magic, the taming of controversies, the separation of black and white magic. The dichotomies listed, according to Szönyi, greatly hinder our understanding of the dynamism and power of the magical world-view around the turn of the seventeenth century.

\footnotetext{
18 "P. Dear, ed., The Scientific Enterprise in Early Modern Europe. Readings from ISIS. (Chicago: University of Chicago Press 1997) p. 2.
}

\section{VI.}

Knowing the scarcity of similar books in Hungarian, it is very understandable, that not a small fragment of Dee scholarship is chosen as the topic, and that the study is wide-ranging. The consequence is, however, that the book is mostly aimed at the 'lay' reader ${ }^{19}$ : but for an introductory book, the meticulous details are somewhat superfluous. If, on the other hand, the book is regarded as an academic monograph, it is not able to compete with the much more detailed and focused works that have appeared in English.

The dilemma is not uniquely Szönyi's, since most Hungarian scholars face the paradoxical situation: they have to opt either for substantial depth or substantial number of readers for a book, to achieve both is usually impossible. To my mind, Szönyi has aimed at both, but his work is more of a good (probably too good) introduction.

And it comes at a very modest price, we may add. The book runs to 300 pages, with an index, a detailed bibliography, some 33 (!) illustrations,

\footnotetext{
${ }^{19}$ Szönyi p. 11.
} 
precise footnotes and references. ${ }^{20}$ The illustrations are unfortunately of mediocre quality. The large number of quotations is very useful, but they are not presented systematically. Sometimes a Latin original is given, but often not; the most curious is when only the last sentence of a longer quotation is reproduced in Latin, even if it has no key importance or great complexity hindering a precise translation.
${ }^{20}$ The asterisks in my footnotes mark works that 1 have not found in Szönyi's bibliography, but are connected to the topic.
The book is a modified version of Szönyi's thesis for the title 'Candidate of Science' written in 1992. ${ }^{21}$ The changes are not fundamental: the structure of the original thesis was retained, and the three parts were used as parts 2-4 in the new book.

GÁBOR ZEMPLÉN
${ }^{21}$ The original title is Keresztény mágia, John Dee és az európai bumanizmus. [Christian magic, John Dee, and European Humanism]. 